\title{
THE DIRECTION OF POSSIBLE CAUSAL RELATIONSHIP BETWEEN FINANCIAL DEVELOPMENT AND \&CONOMIC GROWTH IN NAMIBIA
}

\author{
Abel N Sindano* \\ SACU Secretariat \\ abel.sindano@sacu.int \\ Esau Kaakunga\# \\ University of Namibia \\ ekaakunga@unam.na
}

July 2011

\begin{abstract}
The study investigates the causal relationship between financial development and economic growth in Namibia. In order to test for the existence of long-run relationships between the variables, the study employs a cointegration and vector error correction model (VECM) technique. The Granger causality test was applied to the variables to test for the direction of causation between variables. The results show that there is a stable long-run relationship between financial development and economic growth. The Granger causality test indicates that the causality runs from economic growth to financial development. The results suggest that the real sector of the economy should be developed further in order to stimulate further development in the economy through policy interventions like industrial development to diversify the economic base, enhance the performance of small and medium enterprises, and improve the performance of the tourism sector, which has great potential for promoting growth.
\end{abstract}

\section{Keywords}

Financial development, economic growth, Granger causality, Namibia

\footnotetext{
* Mr Abel N Sindano is a trade data analyst at the SACU Secretariat, Namibia.

\# Dr Esau Kaakunga is a senior lecturer in the Department of Economics at University of Namibia, Windhoek, Namibia.
} 


\section{INTRODUCTION}

Financial development is usually defined as a process that makes an improvement in the quantity, quality, and efficiency of financial intermediary services. The relationship between financial development and economic growth has been comprehensively treated in the theoretical and empirical literature, but economists hold different perspectives on the direction of the relationship. In the literature on the relationship between financial development and economic growth, one question has remained inconclusive and that is whether policy-makers should first pursue financial development, or economic growth, or whether they should pursue both financial development and economic growth at the same time.

Firstly, Robinson, as cited in Arestis and Demetriades (1996), argued that growth in the financial sector follows rather than leads economic growth. This view is called the demand-leading approach. Secondly, McKinnon, as cited in Aretis and Demetriades (1996), argued that the financial system plays a critical role in reallocating resources to the most productive investments, which in turn leads to high economic growth. This latter argument has been supported by empirical work using cross-country data by King and Levine (1993), among other studies. This view postulates the supply-leading approach. Thirdly, there are views that contend that both financial development and economic growth are positively interdependent and their relationship could lead to feedback causality. Luintel and Khan (1999) render support to this argument.

The financial system in Namibia is relatively young and is regarded as well-developed compared to financial systems in Sub-Saharan Africa. Namibia has a dual financial system made up of formal and informal sectors. This study focuses on the commercial banking sector, as it is the most dominant sector in the financial system in Namibia and the one that plays a clearer intermediary role than any other type of financial institution.

The interest in investigating the relationship between economic growth and financial development in Namibia is motivated by two factors. Firstly, a well-developed domestic financial sector can contribute significantly to raising the savings rate, the investment rate and, hence, this will transmit to the economic growth (Huisen, 1999). A well-developed financial system mobilises savings by channelling the small denomination savings into profitable largescale investments. These savings might not be available for investment without the participation of financial institutions, because mobilising the savings of disparate savers is usually costly due to the existence of information asymmetries and transaction costs. Secondly, financial development can also affect the productivity of capital in two major ways - one, by collecting and processing information needed to evaluate the alternative investment projects, hence improving the allocation of resources, and two, by providing opportunities to investors to diversify and hedge risks, thereby inducing individuals to invest in riskier but more productive investment alternatives (Huisen, 1999).

The importance of the debate for developing countries stems from the fact that it has important policy implications concerning whether the policy-makers should first pursue financial development in order to induce higher levels of economic growth or whether they should first concentrate on the development of the real sector in order to stimulate higher levels of financial development. The objective of this study is to contribute to the existing debate on the causal relationship between financial development and economic growth, using Namibia as a case study. 
The rest of the study is organised as follows: section two reviews the economic development and financial system in Namibia, section three presents a theoretical and empirical literature review, section four discusses the methodology, section five contains the empirical analysis and interpretation, and chapter six gives the conclusions and policy implications.

\section{OVERVIEW OF THE ECONOMIC DEVELOPMENT AND FINANCIAL SYSTEM IN NAMIBIA}

\subsection{Economic performance}

Namibia achieved independence on 21 March 1990. Namibia's population stood at 1.4 million in 1991; however, by 2007 it was estimated to be 2 million. The country has an average growth rate of $1.8 \%$ per annum (Central Bureau of Statistics, 2008). The unemployment rate in 2004 was estimated to be $37 \%$ according to the broad definition of unemployment, while by the strict definition it is estimated at 20.2\% (Republic of Namibia, Namibia Labour Force Survey, 2004). This was two percentage points higher than the equivalent rate recorded in 2000. A dispersed population, erratic climate, unemployment, poverty, HIV/AIDS and other contagious diseases such as tuberculosis are among the major challenges facing the country's economy and its population. One feature of the economy is the primary industries' predominance in the total economic activity. With this strong primary industry, Namibia has an ideal opportunity to develop its secondary industries. The reason why this development has not materialised is that raw materials are exploited and exported in a relatively unprocessed state.

According to the Central Bureau of Statistics (2008), during the period of 1980-1989, before independence, the economy recorded an average growth of $1.1 \%$. The engine behind this growth was mainly the tertiary industry, which recorded an average growth of $3.7 \%$, while the secondary and primary industries recorded an average growth of $0.8 \%$ and $-1.4 \%$, respectively. The low average growth rate was mainly due to poor performance in the mining industry.

The growth rate improved to an average of 3.6\% for the period 1990-1998. During this period primary industry on average grew by $3.6 \%$, while the secondary and tertiary industries both grew by $3.5 \%$. This is mainly attributed to good performance in the fishing industry. Further improvement was recorded during the period 1999-2007, which registered an average growth of $4.3 \%$. For this period the primary sector recorded an average growth of $4 \%$, while the secondary and tertiary industries registered growth of $4.6 \%$ and $4.8 \%$, respectively (Central Bureau of Statistics, 2008).

The structure of the economy has basically remained the same as it was before independence. The contribution of the primary sector to GDP on average was $32.8 \%$ for the period 1980-1989, which has since declined to $21.3 \%$ and $21.2 \%$ for the period 1990-1998 and 1999-2007 respectively. This was mainly due to the mining and quarrying sector, which recorded an average contribution of $23.7 \%$ for the period $1980-1989$, drastically declining to $11.0 \%$ for the period 1990-1998, and registering $11.1 \%$ for the period 1999-2007. The secondary sector average contribution to GDP was $15.9 \%$ for the period 1980-1989, while for the period 1990-1998 and 1999-2007 the sector recorded an average contribution of $15.7 \%$ and $16.5 \%$, respectively. The tertiary industry is the biggest contributor to GDP, recording an average contribution of $45.2 \%$ for the period 1980-1989. The role of this industry increased further during the period $1990-$ 1998 , recording an average contribution of $52.8 \%$, while for the period 1999-2007 the industry 
contributed on average $53.7 \%$ of the GDP (Bank of Namibia, 2008).

\subsection{Structure of the financial system}

Namibia has a dual financial system comprising the formal and informal sectors. The formal sector includes the central bank, commercial banks, post office savings bank, insurance companies, pension funds, asset management companies and a stock exchange. The informal sector comprises cash loan operators, moneylenders, pawnbrokers and others. In addition, there is a development finance institution in Namibia, Namibia Development Bank.

Namibia's monetary policy stance is designed to support the fixed exchange rate system between the Namibian Dollar and South African Rand, under the common monetary area (CMA). The exchange rates between the participating countries are fixed to the South African Rand and the movement of capital is free. The major instrument of monetary policy used by the Bank of Namibia is the bank rate. The Bank of Namibia adjusts the bank rate in line with the monetary policy stance of the South African Reserve Bank. However, the Bank of Namibia has the ability to deviate to some extent from the South African Reserve Bank stance by using capital controls and prudential requirements that can be imposed on financial institutions. It is, therefore, possible, when so required, for the Bank of Namibia to maintain a repo rate different from the repo rate of the South African Reserve Bank, and this gives the Bank of Namibia discretion to control the domestic money supply.

Commercial banks are dominant in the financial sector of Namibia and play a clearer intermediary role than any other type of financial institution. There are no formal barriers to entry to the banking sector, but the high initial capital outlay required might serve as a barrier to entry. Currently there are four commercial banks (Bank Windhoek, Standard Bank, Nedbank, and First National Bank) in the country, with total assets valued at $N \$ 36.5$ billion as at 31 December 2007. Commercial banks in Namibia basically offer the same facilities, and thus competition in this sector is mainly non-price (not based on interest rate and service charge variation) but rather by way of competitive advertising and improvement of quality product packaging and service.

The Namibia Post Office Saving Bank is the only savings bank in Namibia. The saving bank does not give loans to its customers. The products offered include savings accounts, savings certificates, save-as-you-earn accounts and fixed-term deposits. The saving bank also offers money transfers. The non-bank financial institutions under consideration are the pension fund corporations, insurance companies and unit trusts. Commercial banks and the non-bank financial institutions both perform the basic role and function of financial intermediation. Money markets debt instruments and claims include the following: call deposits with Bank of Namibia, call deposits with commercial banks, inter-bank loans, banker's acceptances, negotiable certificates of deposit, treasury bills, overdrafts with Bank of Namibia and Agricultural Bank Bills. The Namibian Stock Exchange (NSX) was established in 1992. Equity, derivatives and interest-bearing securities can be listed and traded on the NSX. The NSX is a dual-listed stock exchange, implying that companies listed on the NSX can list on other stock markets as well. Government bonds have also been listed on the NSX (Bank of Namibia, 2001).

\section{LITERATURE REVIEW}

The relationship between financial development and economic growth has received a great deal 
of attention in the modern history of economics. This theoretical relationship dates back to the work of Schumpeter (1911), who emphasised that financial services are paramount in promoting economic growth. Several studies have addressed the potential links between financial development and economic growth (Levine, 1997). Alternative views on the links between financial intermediation and economic growth focus on the key functions of the financial systems. These include, firstly, acting as an effective conduit for channelling funds from surplus to deficit units by mobilising resources and ensuring an efficient transformation of funds into real productive capital. Secondly, financial intermediation transforms the maturity of the portfolios of savers and investors, while providing sufficient liquidity to the system as the need arises. The third function is risk reduction from the system through diversification and the technique of risk sharing and pooling. By so doing, a modern financial system may spur economic growth. However, despite the rapidly growing literature, the debate concerning the role played by the development of financial intermediaries in economic growth is far from settled.

The early models on financial intermediation and economic growth lacked solid modelling of the exact mechanisms of the relationship between the two variables. In the 1990s many new theoretical contributions on how financial intermediation may affect economic growth emerged (Greenwood \& Jovanovic, 1990). The wave of new theoretical models on the relationship between financial development and economic growth has triggered new empirical interest in the relationship between finance and growth (King \& Levine, 1993), which extended the crosscountry framework introduced in Barro (1991) by adding a financial variable to the standard growth regression. Most of the cross-country studies do not pay much attention to the direction of causality. They seem to assume implicitly that financial development causes economic growth in line with the supply-leading view (Patrick, 1966). However, financial development may also be demand-driven (Saint-Paul, 1992). In addition, there may be a two-way causation, where, on the one hand, growth stimulates the creation and growth of financial intermediaries, whereas, on the other hand, these intermediaries contribute to higher growth (Greenwood \& Jovanovic, 1990).

Recently, some studies emerged with attempts to get around the above-mentioned problems. In these studies, explicit attention is given both to the question of whether sample countries can be pooled and to the time series properties of the data. Moreover, Johansen's method based on vector error-correction mechanisms (ECM) is used to test for long-run cointegration between financial development and economic growth (Fan, et al, 1995). This methodology allows formal testing of short-run and long-run causality between finance and growth. By specifying and estimating models for individual countries, these studies show that results are country-specific. The studies deny that financial sector development in general is a determining factor in the process of economic development.

The majority of the panel and cross-country studies on financial development and economic growth find that financial development has a positive effect on economic growth. These studies also provide some empirical evidence for the hypothesis that it is the overall provision of financial services that is important, and not whether a country has a bank-based or marketbased financial system (Levine, 1998). However, the cross-country type of studies are not without problems, since they do not properly account for time dimension. Moreover, crosscountry estimates can give a wrong impression of the impact of financial development on economic growth since they assume that the different countries in the model are homogeneous entities. Since countries may differ greatly with respect to institutions and economic policies used, results may be country-specific. It is argued that while cross-country studies show 
evidence for a positive relationship between financial development and economic growth, the causality between the two remains unclear.

Empirical work on financial development and economic growth in Botswana shows evidence that supports Schumpeter's view that financial development leads to economic growth (Eita \& Jordaan, 2007). These empirical results illustrate that the development of the financial sector in Botswana is important for its economic growth and development. This suggests that financial deepening and institutional reforms should be enhanced to promote Botswana's economic growth.

The empirical results of a study on the causal relationship between financial development and economic growth, which used data for South Africa, Kenya, and Tanzania, show that the direction of the causality between financial development and economic growth is sensitive to the choice of measurement for financial development (Odhiambo, 2007). A demand-leading view was found to be stronger in South Africa and Kenya, while in Tanzania a supply-leading response was found to be strong. These findings are also consistent with Patrick's hypothesis (Patrick, 1966), which postulates that the direction of causality between financial development and economic growth changes over the course of development. A study examining the causal relationship between financial development and economic growth in Malaysia found that economic growth leads to financial development (Ang \& McKibbin, 2005). Findings of the study into the relationship between development of the financial sector and economic growth for Egypt over the time period 1967-1996 confirm the importance of the development of the financial sector and economic growth, with a rise in the ratio of private credit to total credit of $1 \%$, leading to an increase of $0.17 \%$ in the real GDP per capita in the long run (Huisen, 1999).

A study examining the causal relationship between financial development and economic growth in Lesotho concluded that there is no causality between finance and growth in either direction (Mohapi \& Motelle, 2007). This is consistent with the findings of Chang, Shan and Morris, and Dawson (as cited in Mohapi \& Motelle, 2007), which show no link between finance and growth. A study conducted in five MENA countries (Algeria, Egypt, Morocco, Syria, and Tunisia) for the past five decades found no evidence of causality between financial development and economic growth in the short-run, whereas long-run causality tests showed that finance follows rather than leads economic growth (Abu-Bader \& Abu-Parn, 2006). Based on these results, they concluded that the financial reforms that most of the countries have undertaken in the past two decades were not successful in achieving the desired results of enhancing economic growth, either by improving efficiency or through increasing resources for capital accumulation. It appears that in some countries' finance affects growth, while in other countries growth determines finance or the causality is twofold. Most importantly, these studies argue that generalisations based on multi-country results may lead to incorrect policy advice at the country level. Moreover, there is still a theoretical debate on the relative importance of stock market development (Singh, 1997).

\section{METHODOLOGY}

\subsection{Technique}

The study uses econometric techniques to determine the causal relationships between the variables of financial development and economic growth in Namibia for the period 1993:1 2007:IV. Since the study uses time series data that is subject to non-stationarity, we employ unit 
root tests to test for stationarity of the different variables used. The study also employs a cointegration test on the different variables used to establish long-run and short-run relationships. The last test is the Granger causality test to determine the direction of the relationship between variables used. In this study, the cointegration and vector error correction model is used to examine the direction of causality between financial development and economic growth. This approach has been used in finance-growth causality studies, among others (Eita \& Jordaan, 2007; Odhiambo, 2007). The Granger causality test method is preferred in this study to other alternative techniques because of its favourable response to both large and small samples (Eita \& Jordaan, 2007). The conventional Granger causality test involves the testing of the null hypothesis that financial development (FD) does not Granger cause economic growth $(\mathrm{Y})$ and vice versa by simply running the following two regressions:

$$
\begin{aligned}
& \Delta Y_{t}=\alpha_{0}+\sum \alpha_{1 i} \Delta Y_{t-i}+\sum \alpha_{2 j} \Delta F D_{t-j}+u_{t} \\
& \Delta F D_{t}=\beta_{0}+\sum \beta_{1 i} \Delta Y_{t-i}+\sum \beta_{2 j} \Delta F D_{t-j}+C_{t}
\end{aligned}
$$

where $u_{t}$ and $C_{t}$ is the white noise error term for the two functions respectively, $Y_{t}$ is the economic growth variable, and $F D_{t}$ financial development proxies (the ratio of credit extended to private sector to nominal GDP; and the ratio of broad money to nominal GDP).

The null hypotheses to be tested are:

1. $H_{0}: \alpha_{2 j}=0$, financial development does not Granger cause economic growth. Rejection of this hypothesis means that financial development Granger causes economic growth.

2. $H_{1}: \beta_{1 i}=0$, economic growth does not Granger cause financial development. Rejection of this hypothesis means that causality runs from economic growth to financial development.

If neither of the hypotheses is rejected, it means that financial development does not Granger cause economic growth and economic growth also does not Granger cause financial development. This indicates that the two variables are independent of each other. If both hypotheses are rejected, then there is bi-directional causality between financial development and economic growth. The use of traditional Granger causality tests suffers from the following methodological deficiencies. First, these standard tests do not examine the basic time series properties of the variables. According to Granger, if the variables are cointegrated, then these tests incorporating differenced variables will be misspecified unless the lagged error correction term is included (Odhiambo, 2007). Second, the majority of these tests turn the series stationary mechanically by differencing the variables and consequently eliminating the long-run information embodied in the original form of the variables.

Given the two methodological deficiencies in the traditional Granger causality method, proper statistical inference can be obtained by analysing the causality relationship on the basis of the error correction model ( $(C M)$. The error correction model allows for the inclusion of the lagged error correction term derived from the cointergration equation. By including the lagged error correction term the long-run information lost through differencing is reintroduced in a statistically acceptable way.

The cointegration equations are stated in equation (3) and (4), while the error correction model equations are stated in equations (5) and (6).

$$
Y_{t}=\delta+\varphi F D_{t}+E C_{1 t}
$$




$$
\begin{aligned}
& F D_{t}=a+\psi Y_{t}+E C_{2 t} \\
& \Delta Y_{t}=\alpha_{0}+\sum \alpha_{1 i} \Delta Y_{t-i}+\sum \alpha_{2 j} \Delta F D_{t-j}+\alpha_{3} E C_{1 t-1}+u_{t} \\
& \Delta F D_{t}=\beta_{0}+\sum \beta_{1 i} \Delta Y_{t-i}+\sum \beta_{2 j} \Delta F D_{t-j}+\beta_{3} E C_{2 t-1}+\varepsilon_{t}
\end{aligned}
$$

In the above, $\Delta$ represents the difference operator, $F D_{t}$ represents the two proxies of financial development, $Y_{t}$ represents economic growth, and $E C_{t-1}$ represents one period lagged error correction term captured from the cointegration regression. The causal inference is obtained through the significance of $\alpha_{3}$ and $\beta_{3}$.

\subsection{Measurement of variables}

Economic growth in this study is proxied by real quarterly GDP. Financial development, on the other hand, is proxied by two variables. Financial development is usually defined as a process that makes improvement in the quantity, quality, and efficiency of financial intermediary services. This process involves the interaction of many activities and institutions, and it cannot be captured by a single measure. The first proxy of financial development is defined as the ratio of broad money to nominal GDP (M2/GDP). This monetization variable is designed to show the real size of the financial sector of a growing economy. The ratio is expected to increase over time if the financial sector grows faster than the real sector of the economy and decrease if the financial sector grows more slowly than the real sector of the economy. The second proxy is the ratio of credit extended to the private sector to nominal GDP. Credit extended to the private sector is assumed to generate increases in investment and productivity to a much larger extent than credit does to the public sector (Eita \& Jordaan, 2007).

\subsubsection{Stationarity}

A data time series is said to be stationary if the mean and variance are constant through time and the value of the covariance between the two time periods depends only on the distance or lag between the two time periods and not the actual time at which the covariance is computed (Gujarati, 2003). However, if the mean and variance change in samples for different time spans, then this type of variable is known as a non-stationary variable. Regression equations with nonstationary variables have serious limitations. Among other problems, their t-ratios and the adjusted R-square will be overestimated. Therefore, all tests become invalid. This is known as the spurious regression problem. In order to avoid the problem of spurious regression, trended data is differenced a minimum number of times to generate a stationary series.

Although there are several tests of stationarity, such as the graphical analysis, the correlogram test and the unit root test, in this study we only discuss one test: the unit root test. The most popular test of stationarity over the past several years has been the unit root test. This test was first developed by Dickey and Fuller in 1970 and is named after them. The Dickey-Fuller (DF) test is applied to regression analysis in the following forms:

$$
\begin{aligned}
& \Delta X_{t}=\delta X_{t-1}+\varepsilon_{t} \\
& \Delta X_{t}=\alpha_{1}+\delta X_{t-1}+\varepsilon_{t} \\
& \Delta X_{t}=\alpha_{1}+\alpha_{2}^{t}+\delta X_{t-1}+\varepsilon_{t}
\end{aligned}
$$


where $X$ denotes the variable to be tested and $t$ is the time variable. In each equation, the null hypothesis is that $\delta=0$, which implies the existence of a unit root; thus the time series is nonstationary. Rejecting the null hypothesis implies that the series is stationary. The DF test assumes that the error terms $\varepsilon_{t}$ are uncorrelated; thus the use of the standard DF test critical values would be invalidated if the error terms in the test are correlated over time, violating the white noise assumption of the DF test. This study uses an Augmented Dickey-Fuller (ADF) test that takes into account any autocorrelation present by adding the lagged values of the dependent variable $\Delta X_{t}$.

$$
\Delta X_{t}=\alpha_{1}+\alpha_{2}^{t+\delta} X_{t-1}+\sum_{i=1}^{m} \beta_{i} \Delta X_{t-1}+\varepsilon_{t}
$$

where $X_{t}$ is the variable, whose time series properties are being investigated, $\Delta$ is the difference operator, $m$ is the number of lagged variables, and $\varepsilon_{t}$ is the random error term.

\subsubsection{Cointegration}

Cointegration is defined as a long-run relation of variables that are linked to form an equilibrium relationship when the individual series themselves are non-stationary in their levels, but become stationary when differenced. Thus, it can be stated that cointegration highlights the existence of a long-run equilibrium to which the system converges overtime. Two of the most widely used tests in modern research for cointegration are the Engle-Granger and Johansen procedures. The Engle-Granger procedure investigates the possibility of cointegration in bivariate models. One of the limitations of the Engle-Granger approach is that it assumes uniqueness of the co-integrating vector. For more than two variables, the approach does not provide a sufficient framework.

This study uses the Johansen procedure, which is based on a vector autoregression (VAR) framework. The Johansen procedure is as follows. Defining a vector $x_{t}$ of $n$ potentially endogenous variables, it is possible to specify the data generating process and model $x_{t}$ as unrestricted vector autoregression (VAR) involving up to $p$-lags of $x_{t}$ specified as:

$$
x_{t}=\mu+A_{1} x_{t-1}+\cdots+A_{p} x_{t-p}+\varepsilon_{t}
$$

where $x_{t}$ is an $(n \times 1)$ vector of the variables that are integrated of order one; $A$ are $(n \times n)$ matrix parameters; and $\varepsilon_{t}$ is an $(n \times 1)$ vector of innovations.

This VAR can be re-written as:

$$
\Delta x_{t}=\mu+\prod x_{t-1}+\sum_{i=1}^{p-1} \Gamma_{i} \Delta x_{t-1}+\varepsilon_{t}
$$

where

$$
\Pi=\sum_{i=1}^{p} A_{i}-I \text { and } \Gamma_{i}=-\sum_{j=i+1}^{p} A_{j}
$$

If the coefficient matrix $\prod$ has reduced to rank $r<n$, then there are $n \times r$ matrices $\alpha$ and $\beta$ each with rank $r$ such that $\prod=\alpha \dot{\beta}$ and $\dot{\beta} x_{t}$ is stationary. $r$ is the numbers of cointegrating relationships, the elements of $\alpha$ are known as the adjustment parameters in the vector error correction model and each column of $\beta$ is a cointegrating vector. It can be shown that for a given $r$, the maximum likelihood estimator of $\beta$ defines the combination of $x_{t-1}$ that yields the $r$ largest canonical correlations of $\Delta x_{t}$ with $x_{t-1}$ after correcting for lagged differences and deterministic variables when present. 


\subsection{Estimation and interpretation of the results}

\subsubsection{Stationarity Tests}

Time series data in this study is tested for stationarity before running the causality test. The tests were carried out in levels and first difference.

TABLE 1: Stationarity test of variables in levels

\begin{tabular}{|c|c|c|c|c|}
\hline \multirow[t]{2}{*}{ Variable } & \multirow[t]{2}{*}{ Model Specification } & \multicolumn{2}{|c|}{ Test Statistics } & \multirow[t]{2}{*}{ Stationary Status } \\
\hline & & Computed & critical & \\
\hline \multirow[t]{2}{*}{ LNGDP } & Constant and trend & -1.669476 & -3.494 & $\mathrm{I}(\mathrm{l})$ \\
\hline & Constant & 1.382588 & -2.916 & $\mathrm{I}(\mathrm{l})$ \\
\hline \multirow[t]{2}{*}{ LNPC/GDP } & Constant and trend & -2.487595 & -3.488 & $\mathrm{I}(1)$ \\
\hline & Constant & -1.358103 & -2.912 & $\mathrm{I}(1)$ \\
\hline \multirow[t]{2}{*}{ LNM2/GDP } & Constant and trend & -3.344022 & -3.488 & $\mathrm{I}(1)$ \\
\hline & Constant & -1.775389 & -2.912 & $\mathrm{I}(1)$ \\
\hline
\end{tabular}

Source: Author's own computation

Note: LN (natural log), PC (private sector credit ratio to GDP), M2 (broad money as a percentage of GDP) The lag length was set based on the Akaike Information Criteria.

Table 1 shows stationarity test results of all variables in levels. At the significance level of $5 \%$ the critical value for the LNGDP variable is greater than the computed $t$-value, and the conclusion is that the LNGDP time series is non-stationary - that is, it contains a unit root. The critical value for the LNPC/GDP variable at the significance level of $5 \%$ is greater than the computed $t$-value; the conclusion is that the LNPC/GDP time series is non-stationary.

The critical value for the LNM2/GDP variable at the significance level of $5 \%$ is greater than the computed $t$-value; thus the LNM2/GDP time series contains a unit root. The next step, therefore, is to difference all the variables once in order to perform stationary tests on differenced variables as presented in Table 2.

The critical value for the LNGDP variable as stipulated in Table 2 at the significance level of $5 \%$ is less than the computed $t$-value; thus the time series is stationary. At the significance level of $5 \%$ the critical value for the LNPC/GDP variable is less than the computed $t$-value, and the conclusion is therefore that the LNPC/GDP time series is stationary. The critical value for the LNM2/GDP variable in Table 2 is less than the computed $t$-value; thus, the conclusion is that the LNM2/GDP time series is stationary. Since the variables are I (1), the next step is to test for cointegration using Johansen's full information maximum likelihood. 
TABLE 2: Stationarity test of variables in first difference

\begin{tabular}{lllll}
\hline \multicolumn{1}{c}{ Variable } & \multicolumn{1}{c}{ Model Specification } & \multicolumn{2}{c}{ Test Statistics } & Stationary Status \\
& & Computed & critical & \\
\hline$\Delta \mathrm{LNGDP}$ & Constant and trend & -9.356092 & -3.494 & $\mathrm{I}(0)$ \\
& Constant & -9.114696 & -2.916 & $\mathrm{I}(0)$ \\
$\Delta \mathrm{LNPC/GDP}$ & Constant and trend & -9.698697 & -3.489 & $\mathrm{I}(0)$ \\
& Constant & -9.684089 & 2.912 & $\mathrm{I}(0)$ \\
& & & & \\
$\Delta \mathrm{LNM2/GDP}$ & Constant and trend & -10.43149 & -3.489 & $\mathrm{I}(0)$ \\
& Constant & -10.51006 & -2.912 & $\mathrm{I}(0)$ \\
\hline
\end{tabular}

Source: Author's own computation

Note: LN (natural log), PC (private sector credit ratio to GDP), M2 (broad money as percentage of GDP)

\subsubsection{Cointegration analysis}

Having confirmed that all variables included in the causality test are integrated of order one as presented in Table 2, the next step is to independently test the existence of the cointegration relationship between each of the proxies for financial development and the GDP. The study uses the Johansen's full information maximum likelihood cointegration test procedure.

TABLE 3: Cointegration test results between LNGDP and LNM2

\begin{tabular}{ccccc}
\hline Null hypothesis & $\begin{array}{c}\text { Alternative } \\
\text { hypothesis }\end{array}$ & Test statistics & $\begin{array}{c}0.05 \\
\text { critical value }\end{array}$ & Probability value \\
\hline$r=0$ & $r=1$ & Trace statistics \\
$r=1$ & $r=2$ & 46.31031 & 20.26184 & 0.0000 \\
& & 5.894088 & 9.164546 & 0.1990 \\
$r=0$ & $r=1$ & Maximum eigen value statistics & 0.0000 \\
& $r=2$ & 40.41623 & 15.8921 & 0.1990 \\
\hline
\end{tabular}

Source: Author's own computation

Given that the computed $t$-statistics are greater than the critical value for both trace statistics and maximum eigen value statistics in Table 3, we do not reject the alternative hypothesis $r=1-$ that is, there is one cointegrating vector between LNGDP and LNM2. 
TABLE 4: Cointegration test results between LNGDP and LNPC

\begin{tabular}{ccccc} 
Null hypothesis & $\begin{array}{c}\text { Alternative } \\
\text { hypothesis }\end{array}$ & Test statistics & $\begin{array}{c}0.05 \\
\text { critical value }\end{array}$ & Probability value \\
\hline$r=0$ & $r=1$ & Trace statistics \\
$r=1$ & $r=2$ & 30.7560 & 20.26184 & 0.0012 \\
& & 7.535563 & 9.164546 & 0.1009 \\
$r=0$ & $r=1$ & Maximum eigen value statistics & 0.0030 \\
& $r=1$ & 23.22043 & 15.8921 & 0.1009
\end{tabular}

Source: Author's own computation

The computed $t$-statistics in Table 4 are greater than the critical value for both trace statistics and maximum eigen value statistics; thus we do not reject the alternative hypothesis $r=1-$ that is, there is one cointegrating vector between LNGDP and LNPC.

\subsubsection{Vector error correction model}

Since there is cointegration as shown in Tables $\mathbf{3}$ and $\mathbf{4}$, the direction of causality is tested by using the vector error correction model (VECM).

\section{TABLE 5: VECM results}

\begin{tabular}{lcc}
\hline \multicolumn{1}{c}{ Variable } & $\beta$ & $\varepsilon C M$ \\
\hline a) variable included in the VAR: LNGDP and LNM2 & & \\
LNGDP & 1.00000 & -0.701407 \\
& & {$[-2.97231]$} \\
LNM2 & -1.820397 & \\
& {$[-4.25179]$} & \\
Constant & -7.438311 & \\
b) variable included in the VAR: LNGDP and LNPRIV & & -0.044132 \\
LNGDP & 1.00000 & {$[-3.75172]$} \\
& & \\
LNPRIV & -1.373243 & $-4.53144]$ \\
Constant & -8.509466 & \\
\hline
\end{tabular}

Source: Author's own computation

The t-statistics are in brackets

The coefficient $(\beta)$ of the measures of financial development are interpreted as positive because they still have to be taken to the right hand side of the equations 
The VECM results in Table $\mathbf{5}$ show that all measures of financial development have a positive influence on GDP. This is evident from the coefficients $(\beta)$ of the measures of financial development, which are negative and significant at one and $5 \%$ levels. This shows that there is a long-run causal relationship between economic growth and financial development. The results in Table 5 reveal that the error correction term is negative and statistically significant at $1 \%$, which implies that the measures of financial development and economic growth are adjusting to their long-run equilibrium relationship.

\subsection{Granger causality test}

The correlation test does not tell anything about the causal relationship between financial development variables and GDP. Thus the Granger causality test is used to examine the direction of the relationship that exists between the variables.

TABLE 6: Granger causality test results between D (LNGDP) and D (LNM2)

\begin{tabular}{lcc}
\hline Null hypothesis & Chi-sq & Probability \\
\hline D(LNGDP) does not Granger cause D(LNM2) & 18.7456 & 0.0021 \\
D(LNM2) does not Granger cause D(LNGDP) & 3.8993 & 0.5640 \\
\hline
\end{tabular}

Source: Author's own computation

From Table 6 we reject the null hypothesis D(LNGDP) does not Granger cause D(LNM2), as it has a low $p$ value, and we do not reject the null hypothesis D (LNM2) does not Granger cause D (LNGDP). Therefore, it appears that Granger causality runs one way from D (LNGDP) to D (LNM2).

TABLE 7: Granger causality test results between D(LNGDP) and D(LNPRIV)

\begin{tabular}{ccc}
\hline Null hypothesis & Chi-sq & Probability \\
\hline D(LNGDP) does not Granger cause D(LNPRIV) & 78.4972 & 0.0000 \\
D(LNPRIV) does not Granger cause D(LNGDP) & 4.5144 & 0.4780 \\
\hline
\end{tabular}

Source: Author's own computation

We reject the null hypothesis D(LNGDP) does not Granger cause D(LNPRIV), as it has a low pvalue, and we do not reject the null hypothesis D(LNPRIV) does not Granger cause D(LNGDP). Thus, the Granger causality runs from D(LNGDP) to D(LNPRIV). The results in Tables $\mathbf{6}$ and $\mathbf{7}$ indicate that the causality runs from economic growth to financial development regardless of the proxy for financial development. The results provide evidence that the relationship between financial development and economic growth follows a demand-leading view in Namibia.

\section{CONCLUSION}

This study has attempted to gauge the standing of the Namibian economy in the unsettled debate of the role of financial intermediation in economic growth. There is an extensive literature on the relationship between financial development and economic growth, and it is now generally agreed that financial development is important for economic growth. However, the direction of causality between financial development and economic growth is not without ambiguity. Knowing the direction of causality is important because it has implications for policy 
development. One could argue that, only in the case of supply-leading, policies should aim to financial sector liberalization; whereas in the case of demand-following, more emphasis should be placed on growth-enhancing policies.

In this study the direction of causality between financial development and economic growth in Namibia was investigated using time series techniques of cointegration and causality. Two alternative proxies of financial development were paired each with the economic growth variable in the cointegration and causality tests. Stationarity tests on the variables revealed that all variables are stationary at first difference. The cointegration test revealed that there is one cointegration vector between economic growth and measures of financial development.

Granger causality tests were carried out in the context of cointegration and vector errorcorrection mechanisms. Overall, the results support Robinson's argument that 'where enterprise leads finance follows', but not the hypothesis that a bank-based financial system induces longterm growth in the real sector. This is a demand-leading view.

The study has established that economic growth Granger causes financial development and thus the study recommends that the real sector of the economy should be developed further in order to stimulate further development in the economy. Possible policies measures include reactivating private investment, industrial development to diversify the economic base, enhancing the performance of small and medium enterprises and improving the performance of the tourism sector, which has great potential for promoting high economic growth.

\section{LIST OF REFERENCES}

Abu-Bader, S. \& Abu-Qarn, A.S. (2006). Financial development and economic growth: empirical evidence from Six MENA Countries. Review of Development Economics, 12(4), pp. 803-817.

Ang, B.J. \& McKibbin, W.J. (2005). Financial liberalization, financial sector development and growth: evidence from Malaysia Brooking discussion paper, No. 168. [0n-line] Available: http://www.brookings.edu/papers/2005/06development_ang.aspx. (Accessed 150 ctober 2008).

Arestis, P. \& Demetriades, P. (1996). Finance and growth: Institutional considerations and causality, University of East London, Department of Economics Working Paper No.5. [0n-line] Available: http://ssrn.com/abstract=35996. (Accessed 010 ctober 2008).

Aziakpono, M.J. (2003). Financial development and economic growth in Southern Africa. National University of Lesotho, Department of Economics, Maseru.

Barro, R. (1991). Economic growth in cross section countries. Quarterly Journal of Economics, 106(2), pp. $407-443$.

Bank of Namibia. Various annual reports. Windhoek.

Bank of Namibia. (2001). Optimal financial structure for Namibia, proceedings of the annual symposium, 2001. Windhoek.

Eita, J.H. \& Jordaan, C.A. (2007). A causality analysis between financial development and economic growth for Botswana, University of Pretoria. Working paper 2007-22. [0n-line] Available: http://ideas.repec.org/p/pre/wpaper/200722.htm/. (Accessed 01 0ctober 2008).

Fan, Y., Li Q., \& Stengos, T. (1995). Root-N-Consistent semi parametric regression with conditional heteroskedastic disturbances. Journal of Quantitative Economics, 11(2), pp. 229-240. 
Greenwood, J. \& Jovanovic, B. (1990). Financial development, growth and the distribution of income. Journal of Political Economy, 98(5), pp. 1076-1108.

Gujarati, D.N. (2003). Basic econometrics, $4^{\text {th }}$ edition. New York: McGraw Hill.

Huisen, K.A. (1999). Finance and growth in Egypt, University of Kent, Department of Economics, Canterbury CT27NP. [On-line] Available: http://www.iceg.org/NE/projects/financial/growth.pdf. (Accessed 01 October 2008).

King, R.G. \& Levine, R. (1993). Finance and growth: Schumpeter might be right. Quarterly Journal of Economics, 108 (3), pp. 717-737.

Levine, R. (1997). Financial development and economic growth: Views and agenda. Journal of Economic Literature, 35(2), pp. 688-726.

Levine, R. (1998). The legal environment, banks, and long-run economic growth. Journal of Money, Credit and Banking, 30(3), pp. 596-620.

Luintel, K.B. \& Khan, M. (1999). A quantitative reassessment of the finance-growth nexus: Evidence from a multivariate VAR. Journal of Development Economics, 60(2), pp. 381-405.

Mohapi, P.L. \& Motelle, S.I. (2007). The finance-growth nexus in Lesotho: causality revelation from alternative proxies. Journal for Studies in Economics and Econometrics, 31(3), pp. 43-59.

Republic of Namibia, Central Bureau of Statistics, Various reports of national accounts, National Planning Commission, Windhoek.

Republic of Namibia. (2004). Labour force survey report, Ministry of Labour and Social welfare, Windhoek.

Odhiambo, N.M. (2007). Supply-leading versus demand-following hypothesis: Empirical evidence for three SSA countries. African Development Review, 19(2), pp. 257-280.

Patrick, H.T. (1966). Financial development and economic growth in underdeveloped countries. Economic Development and Cultural change, 14(2), pp. 174-189.

Saint-Paul, G. (1992). Technological choice, financial markets and economic development. European Economic Review, 36, pp. 763-781.

Schumpeter, J.A. (1911). The theory of economic development. Cambridge: Harvard University Press.

Singh, A. (1997). Financial liberalization, stock markets and economic development. Economic Journal, 107 (442), pp. 771-782. 
POSSIBLE CAUSAL RELATIONSHIP BETWEEN FINANCIAL DEVELOPMENT AND ECONOMIC GROWTH IN NAMIBIA 